\title{
BESTIÁRIO DA LITERATURA DA GUERRA COLONIAL PORTUGUESA (ALGUMAS CONSIDERAÇÕES)
}

\author{
Norberto do Vale Cardoso ${ }^{1}$
}

\begin{abstract}
Resumo: Perscrutando várias obras que tratam o tema do colonialismo e da guerra colonial portuguesa, de entre elas sublinhando a obra de António Lobo Antunes, concluímos não haver uma epopeia que cante, como Os Lusíadas o fazem, o papel do português que combateu nessa guerra. Talvez essa falha de representação (conectada com a urgência em denegar e obliterar as memórias de um tempo em que um país, cuja posição europeia era subalterna, só em África se pensava próspero) derive do facto de o jovem português mobilizado para as colónias africanas não ter tido um papel linear. Efectivamente, a sua acção foi pautada por um desempenho dual, entre a prosperização e o alquebramento de um regime que, por um lado, se sustentava na guerra e, por outro, falhará exactamente através dela. O combatente português desliza para uma hesitação identitária ao nível pessoal e, sobretudo, social, parcialmente resolvida através de um bestiário onde se incluem o lobo e, sobretudo, o cão (imagens que alegorizam a transformação sofrida pelos jovens combatentes). Propomos, pois, que tenha sido na guerra colonial que melhor se tenham espelhado tais binómios: a) a experiência agónica que animaliza (ou canibaliza) o soldado; b) a experiência enquanto conhecimento que o leva a reavaliar a sua identidade individual e, extrapolando, a identidade colectiva.
\end{abstract}

Palavras-chave: Bestiário; Guerra Colonial Portuguesa; Cão; Caliban; Canibal.

\section{BESTIARY ON THE LITERATURE OF THE PORTUGUESE COLONIAL WAR (A FEW THOUGHTS)}

\begin{abstract}
Reading some of the works on colonialism and the Portuguese colonial war, stressing, among them, the work of António Lobo Antunes, we figure that there is no epic text which sings, like Camoes does in The Lusiads, the role of the contemporary Portuguese soldier. As a matter of fact, in democracy Portugal intended to deny and forget the memories of its colonial past. The Portuguese soldier didn't have a straight role, though he represents both sides: on the one hand, the Portuguese regime and his will to stick to an image of a great nation, besides Europe's different concept and the weakness of that regime which was running out of time, on the other hand. So, his performance stays between prosperity and lack of strength, which leads us into an identity hesitation, solved only by a bestiary in which we must include the wolf and, most of all, the dog. We suggest that it is during the Portuguese colonial war that we can find the binomial forces that explain those issues: a) the agony of men (transformed in a cannibal), suffering, changing and doubting of himself, b) which is also the agony of a collective time.
\end{abstract}

Key-words: Bestiary; Portuguese Colonial War; Dog; Caliban; Cannibal.

\footnotetext{
1 Professor Doutorado em Ciências da Literatura - Literatura Portuguesa, pela Universidade do Minho, atualmente no Instituto Politécnico de Bragança, Portugal.
} 
Para Rui Bebiano, a leitura da ficção portuguesa contemporânea faz-nos sentir “órfãos do Estado Novo, na medida em que as versões de identidade que encontramos não são alternativas suficientemente fortes" (BEBIANO, 2000, p. 569). Gostaríamos, nesse sentido, de sublinhar as ambiências criadas por José Cardoso Pires, sobretudo em Balada da Praia dos Cães, que, segundo Peter Petrov, cria "uma cosmovisão de foro particularmente crítico” (PETROV, 2006, p. 11). O livro inicia-se com a descoberta - casual - de um cadáver, que é encontrado entre as dunas da Praia por "uma conspiração de cães", que rasgam peças do vestuário e se abocanham entre si. Esta é a imagem em que a depuração cardoseana nos faz vislumbrar um país através de uma Praia (sinédoque que suscita a reminiscência do verso camoniano "Ocidental Praia Lusitana", (CAMÕES, 1992, p. 43)). Este intróito faz-nos entender que, nessa Praia, pejada de Cães "à volta de um cadáver", toca uma Balada carunchosa (PIRES, 2001, p. 6-7) oposta ao canto epopeico. Efectivamente, a Praia de onde partiram os navegadores portugueses em prol de uma missão que se entendia ser civilizacional, é agora o local de chegada dos cadáveres, co o, de resto, parece ter sido previsto pela personagem do Velho do Restelo (canto IV d' Os Lusíadas). A Praia terá deixado de ser o lugar do sonho para ser uma espécie de cemitério onde estão depositados os restos de um país.

A Balada da Praia dos Cães, como romance eminentemente policial, coloca-nos perante sentidos multímodos, como, de resto, se pode verificar quando a polícia refere que a vítima encontrada na praia gostava de cães, colocando em causa o símbolo do cão (simbolicamente tão relevante quanto complexo), que se situa, grosso modo, entre a fidelidade e a traição. Localizada durante os anos do Estado Novo, a narrativa de José Cardoso Pires tece referências subtis ao conflito militar travado entre 1961 e 1975 nas hoje ex-colónias portuguesas, mas os cães surgirão, a par dos lobos, como um dos símbolos centrais do 'bestiário' dessa guerra. Conhecida como guerra colonial ou guerra do ultramar, esta encontra, de facto, várias representações em outros autores (com destaque para a obra de António Lobo Antunes, como adiante explanaremos), onde os cães adquirem lugar proeminente para melhor compreendemos o outro lado desse tempo: o da guerra como uma canibalização dos soldados portugueses que participaram nesse conflito, devendo aqui a palavra 'canibalização' ser entendida num sentido pejorativo, fruto de incompreensões e 
silêncios estabelecidos para com essa época que se desejava forçosamente obliterar da memória sob o pretexto (igualmente ambíguo) de a superar.

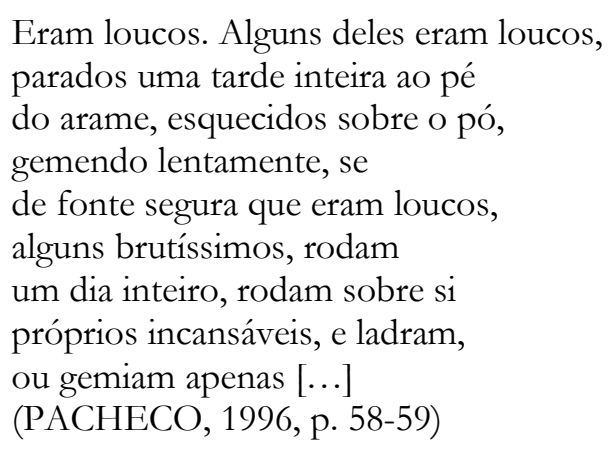

O poema "Os cães", de Fernando Assis Pacheco é uma metáfora do comportamento humano na guerra. O autor de A Musa Irregular (1996) participou na guerra colonial, uma guerra de guerrilha, não convencional, em que não havia uma separação clara entre os opositores (uma vez que não existiam campos de batalha no sentido tradicional do termo) e os seus inimigos se misturavam com a população. As emboscadas faziam dessa uma guerra em que os portugueses não conheciam o rosto do inimigo, o que os levava a travar um conflito baseado em conjecturas, onde o outro não era concreto. Esse aspecto reveste-se de altos índices de stresse que podem levar a comportamentos anómalos, agressivos, mesmo violentos, pois é na guerra que o ser humano mais parece regressar a um estado mais próximo do instinto de sobrevivência que caracteriza um qualquer animal.

Não pode estar aqui em causa a ideia de que há animais mais agressivos que outros, apesar de os geneticistas terem identificado que o padrão cromossómico XYY representa maior agressividade. Segundo esses estudos, "cerca de um homem em cada mil herda dois cromossomas Y em vez do habitual cromossoma Y único, e o grupo XYY produz um número ligeiramente desproporcionado de criminosos violentos.” (KEEGAN, 2006, p. 122) A agressividade pode resultar de uma predisposição genética, mas o que está em causa no poema de Fernando Assis Pacheco será, antes de mais, o modo como homens comuns, retirados da sua vida rotineira (em grande parte dedicados à actividade primária, iletrados e analfabetos, se nos referirmos à época em concreto), são conduzidos a uma situação-limite que os transforma.

Fernando Assis Pacheco, o poeta de Respiração Assistida - livro póstumo que tem como substância central a guerra de onde o poeta foi evacuado por "neurose de guerra", 
tendo estado internado no Hospital da Estrela durante quatro meses -, refere-se precisamente a um "enlouquecimento" dos soldados através de uma poderosa e sustentada metáfora: os cães "furiosos" e "loucos" (PACHECO, 1996, p. 59) que, como o tempo que se suspendia, paravam junto ao arame e, de pé, se esqueciam de tudo o resto. Os cães que estavam de pé e, depois, sem resistência, se deitavam, eram, alegoricamente, os próprios soldados, o que sublinha a metamorfose daqueles homens e a luta inglória por manterem as suas crenças (não raramente ligadas a um cristianismo exacerbado num país religioso onde Fátima era um dos três pilares essenciais): "a merda destes cães deitados/ porque em pé, percebes, eu já/ não (aguento) e fiz o possível” (PACHECO, 1996, p. 59).

Fernando Assis Pacheco descreve, pois, o ambiente que rodeava os soldados e os enlouquecia, transformando-os em "cães", o que, por um lado, destrói a memória anterior (jovens adultos com uma identidade formada) e, por outro, acaba por colocar em causa a sua própria auto-representação. Esta constatação parece corroborar a perspectiva veiculada pela sociologia militar, pois os sociólogos militares “aceitam como premissa a proposição de que qualquer sistema de organização militar expressa a ordem social a partir da qual floresce" (KEEGAN, 2006, p. 293). Por conseguinte, mais do que herdar geneticamente a tendência para a violência, os soldados são fruto de circunstâncias anómalas que alteram a sua conduta. Esses jovens, cercados pelo arame, que se tornavam em feras ou seres "brutíssimos", começavam a ladrar e a gemer, rodando sobre si próprios. Este movimento, equivalente à rotação da Terra, parece, para Assis Pacheco, implicar que o mundo "rode", ou seja, que o mundo esteja já descoberto e afastado de uma visão escolástica, inquisitorial e geocêntrica, o que, em suma, injustifica aquela guerra, enformando-a como um acto bélico perfeitamente anacrónico. Além do mais, o soldado quedo junto ao arame e, assim, descentrado no universo, representa esse eterno retorno da História a uma fase primitiva da guerra e incipiente ao nível de conhecimento. Contudo, o soldado "roda" porque, afinal, se transforma em algo que não era. Se este pode ser um acto de Humanismo, em que o Homem, pela experiência, pela empiria, adquire um conhecimento muito específico, alterando a sua concepção do mundo, é-o - não esqueçamos - através da sua própria desumanização.

Segundo Margarida Calafate Ribeiro, Fernando Assis Pacheco converte "o mundo dos homens no mundo dos cães" (RIBEIRO, 2004, p. 215), pois ambos estarão "parados em frente ao arame do quartel ou rodando em círculos intermináveis de espera e abandono". Ora, as memórias que os vindouros terão desse tempo serão alvo de 
“escárnio", pois estes virão “com seus cães que se deitam aos pés das pessoas e parecem/ adivinhar a linguagem monstruosa/ das narinas resfolegando" (PACHECO, 1996, p. 107). Eis que o "cão" se faz representante da morte, pois em grande parte das culturas este animal liga-se à morte, seja por se acreditar que o dono deve ser sepultado com o cão (na América Central), seja porque os mortos, doentes e velhos são lançados aos cães (na Pérsia), ou porque o cão acompanha o morto aos infernos ou é deste guardião (mitologia geral) (cf. CHEVALIER e GHEERBRANT, 1994, p. 152). Portanto, o cão é um símbolo mítico ancestral, que pode comportar uma extensa série de simbologias. Sublinhamos uma, que pode ser ligada à guerra colonial como ela é vista pela larga maioria dos seus escritores, e, neste caso, por Fernando Assis Pacheco: referimo-nos a uma crença congolesa, que, no intuito de encontrar o culpado pela morte de alguém entre a aldeia dos Bantos, os leva a pendurar o corpo do cão por considerarem que este acto levará o culpado a cair doente. Esta crença liga o cão ao dom da clarividência.

Ponderando os sentidos aqui subjacentes, devemos considerar a hipótese de Assis Pacheco se referir ao sacrifício dos cães como necessário para que os vindouros compreendam que os soldados foram, na larga maioria dos casos, contrafeitos para esse conflito onde, fruto de circunstâncias muito particulares, e obrigados a um processo de adaptação e transformação das suas condutas. Talvez por isso Assis Pacheco se refira ao esquecimento da morte como uma "maldição" (PACHECO, 1996, p. 107). Nesse sentido, também ele seria metamorfoseado num cão, que, regressado dos mortos, vem mudar a consciência do pai, que o impelira a fazer a guerra (cf. RIBEIRO, 2004, p. 207-208), e a quem Assis Pacheco dedica um poema da guerra. E talvez também por esse motivo a sua Musa seja Irregular, isto é, talvez por esse motivo a guerra colonial venha demonstrar, literariamente, que estes homens não são heróis ou "barões" cantados e/ ou assinalados comos os d' Os Lusíadas. A serem heróis, são-no numa inversão, que a literatura vem pugnando, até uma determinada altura, como sendo uma constante "nostalgia de Império perdido" (COELHO, 1992, p. 67).

O "colonialismo" passará também (e sem que muitos disso se apercebam num tempo pretensamente pós-colonial) pela 'colonização' dos sentidos da guerra e dos sujeitos que a protagonizaram. Vejamos atentamente, a esse propósito, o caso de um grupo de 
veteranos de guerra que vive uma vida civil aparentemente normal em Os Lobos Não Usam Coleira (1995), de Carlos Vale Ferraz. A aparente vulgaridade em que vivem é uma pele que oculta um estado "adormecido" que se caracteriza por comportamentos imprevisíveis, como por exemplo o exercício da violência. Assim o caracteriza a mulher de Roberto Alua, um ex-combatente da guerra colonial que, na vida civil actual, trabalha num banco em que ninguém o parece conhecer muito bem: "Nunca suspeitei que tivesse tanta violência entranhada no corpo! [...] Um tipo imprevisível e surpreendente” (FERRAZ, 1995, p. 26). Mas é primordialmente em grupo que essa máscara se revela. Na narrativa de Os Lobos Não Usam Coleira investiga-se o estranho desaparecimento de um grupo de homens, mais ou menos na mesma altura do ano, o que desperta a curiosidade de um inspector que vive o trauma da perda de um filho na guerra em África. O detective Malarranha tem, pois, um sentimento ambíguo para com o grupo auto-intitulado de «Os Imortais»: um misto de condenação e admiração ("aquilo que unia os quatro imortais fascinava-o com uma força muito superior ao desejo de os ver desmembrados", FERRAZ, 1995, p. 109), porque se questiona sobre o que os permitiu regressar da mesma guerra onde o seu filho morreu de uma "morte estúpida" (FERRAZ, 1995, p. 16). Esta ambiguidade parece ser uma tentativa de redenção e de expiação do próprio Malarranha.

O mesmo se diz de Horácio Lobo, o mais afectado pela violência da guerra e temido pelas suas “inesperadas reacções” (FERRAZ, 1995, p. 91). Horácio Lobo é, de todo o grupo, o mais incontrolável, o que mais facilmente explode (FERRAZ, 1995, p. 95). A máscara é colocada pela stásis devido a uma exigência social: a necessidade de readaptação e de apagamento do hiato vivencial criado pela guerra. Todavia, por detrás da máscara oculta-se a verdadeira identidade, a do "lobo". Quando esta se manifesta, constitui para qualquer um que os acompanha "uma descida aos infernos" (FERRAZ, 1995, p. 118), pois o grupo unido age pelos instintos, torna-se animalesco, e reage como se estivesse ainda em guerra. Vejamos uma definição da identidade do ex-combatente:

São tipos de vida dupla, às claras parecem normais, transmitindo uma permanente tensão que os torna atractivos nos primeiros contactos, no entanto, debaixo dessa aparência divertida e aventureira escondem-se seres que não distinguem o bem do mal, para quem o mundo é um objecto de que se servem como lobos esfomeados. (FERRAZ, 1995, p. 118) 
A sua identidade não é feita senão de múltiplas máscaras. Os imortais têm, pois, uma "vida dupla, tripla", o que os leva a considerar "impunes", “acima das leis" (FERRAZ, 1995, p. 100), ou seja, o que os leva a considerar que a sua lei é a lei da guerra, o que implica, na prática, a ausência de leis, de constrangimentos, de regras. Os imortais são seres com uma identidade amaldiçoada, porque eles são os hospedeiros em que a guerra sobrevive: "Nunca mais terás descanso, o teu espírito arderá eternamente sem se consumir e no universo não se reunirá força capaz de o extinguir." (FERRAZ, 1995, p. 63) A identidade criada na guerra sobrepõe-se a outras, e esse tempo não parece ser um mero hiato, antes uma constância substitutiva de todos os outros tempos. A verdadeira identidade é a imortalidade da guerra em cada um que a fez. Efectivamente, quando estão juntos, os quatro formam um grupo que se sente oprimido pela paz (FERRAZ, 1995, p. 74), porque a realidade pós-guerra é opressora da identidade em que a guerra os enformou: "continuam a fazer a guerra aquil" (FERRAZ, 1995, p. 75). Vejamos ainda uma outra definição

Falam da guerra com gozo arrepiante, sem remorsos. A lembrança desses feitos excita-os e aflige-os como uma terrível dor de cabeça, até um deles sofrer ataques epilépticos, outro ficar impotente, e o mais perigoso quase incendiar um restaurante! Sofrem dos medos mais primários, fogem do escuro e procuram o calor do fogo para se refugiarem, como as crianças. Têm alucinações e falhas de memória. $\mathrm{O}$ tempo presente desorienta-os e misturam-no com o passado. Tão depressa caem numa melancolia assustadora, num silêncio tremendo, como falam todos ao mesmo tempo. (FERRAZ, 1995, p. 119)

Ao agirem pelos instintos, são como "lobos", seres livres, incontroláveis, não domesticáveis. O tempo que passam no Algarve (para onde partem anualmente) leva esse Homo Lupus em que cada um se transformou a assaltar um banco, um acto perpetrado em "alcateia" e que visa, tal como os lobos, assaltar uma entidade que representa a organização, a regra, o poder e a paz que eles, na verdade, não readquiriram. O casus belli é, aqui, uma adulteração da identidade primordial que estes homens tinham antes da guerra, pois, para todos os efeitos, "haviam sido corrompidos até ao âmago e nunca mais proporcionariam uma réstia de felicidade ou de prazer a quem estivesse ao seu lado" (FERRAZ, 1995, p. 122). Há, pois, aqui uma dicotomia entre o que eram antes e depois, o que nos parece corroborar a perspectiva "sociologista da guerra", que refere o acto bélico como estranho ao Homem e produto das relações sociais (BEBIANO, 2000, p. 77). 
A ligação entre o "cão" e o "lobo", que acabámos de sublinhar, parece-nos aqui pertinente, uma vez que as mesmas se ligam a um nível semântico das representações da guerra colonial portuguesa, apresentando-nos um ser híbrido e enormemente simbólico. $\mathrm{Na}$ crença medieval era abundante a imagem do "lobisomem", muitas vezes encarado como a encarnação do próprio diabo (MARTINEZ e MAXWELL, 2007, p. 503). Ora, como sabemos, o demónio é aquele que tenta Judas Iscariotes, figura proeminente em António Lobo Antunes, não apenas, mas sobretudo, em Os Cus de Judas (1979)².

Cabe, primeiramente, referir que o protagonista dos primeiros romances de Lobo Antunes, um médico regressado da guerra colonial, se relaciona com a questão que era já de mister para Jean-Jacques Rousseau (ROUSSEAU, 1999, p. 13) que, considerando que todo o homem nasce livre mas vive em toda a parte aprisionado, se pergunta sobre o modo como se processa essa modificação. No caso da obra de António Lobo Antunes parece aplicar-se, sob o nosso ponto de vista, precisamente a teoria do autor de O Contrato Social, uma vez que a família (mais antiga e primeira sociedade política) modela o indivíduo, como sucede nos primeiros romances, Memória de Elefante e Os Cus de Judas, em que as tias e a mãe (as entidades femininas consanguíneas) são representadas pelas actividades manuais do “crochet” (ANTUNES, 2007a, p. 26, 83, 124) e do "tricot” (ANTUNES, 2008, p. 33).

Não obstante, essa "urdidura", ao invés da de Penélope na Odisseia, não se (des)faz em movimentos contínuos de realinhamento da vida, antes parece elaborar-se num movimento de ruptura expectante, que considera que a guerra há-de tornar melhor o protagonista dos dois primeiros romances. Esta perspectiva de engrandecimento do homem pela actividade bélica revela-se gorada aquando do regresso do sujeito a Lisboa e não é corroborada pela própria personagem de Memória de Elefante, que contesta quem não espera por ele, assim como aqueles que acabaram, na sua ausência, por fazer a sua vida "para a frente" (formação académica em Paris ou Londres). Ora, é o sujeito que regressa da guerra que percebe que a sua vida foi feita "para trás" e que, por isso, ele é uma espécie de "Lázaro". Ele tem uma outra formação, mas esta, baseada na experiência, exige-lhe “(re)fazer” a vida como se ele fosse a sua própria Penélope.

\footnotetext{
${ }^{2}$ Segundo algumas fontes, o livro referido foi publicado no Brasil sob dois títulos, primeiro conforme o original, Os Cus de Judas, e mais tarde com o título Os Cafundós do Judas (cf. CARVALHO, 1999).
} 
Eis que os primeiros romances rompem e colocam em causa o modelo tradicional da família (e.g. a proto-memória, vivida como uma edipianização do sujeito). Rosseau (ROUSSEAU, 1999, p. 19) também defende que a guerra, como o acto humano que mais animaliza o homem (que o torna no Homini Lúpus), será, afinal, de uma relação entre Estados, e não entre pessoas. Este apontamento é proeminente na obra de António Lobo Antunes e é-o sobremaneira quando o protagonista dos romances iniciais enceta elos aos sobas, aos guerrilheiros ou aos povos autóctones, apreendendo que a guerra não é especificamente contra aqueles homens, mas contra o seu Estado, por um lado, e, mais agónico, contra si próprio, por outro.

Cabe aqui sublinhar que a guerra colonial, iniciada em Angola, em 1961, é uma guerra do Estado português, o Estado Novo, que defende, de forma contraproducente, uma defesa anacrónica que vai contra o curso tomado pela História na segunda metade do século XX. O modo como António Lobo Antunes relata a transformação sofrida pelo soldado português de então inicia-se nas próprias cartas escritas pelo alferes a sua mulher, reunidas no livro Cartas da Guerra (ANTUNES, 2005), um texto não ficcional, mas com laivos de ficcionalidade, que, por isso mesmo, apelidamos de proto-romance. Vejamos um exemplo da referência aos cães nessas cartas: “A questão dos cães é aflitiva: por todos os aquartelamentos, $[. .$.$] , os cães pululam em magotes indescritíveis, muitos deles com feridas$ e chagas" (ANTUNES, 2005, p. 89).

Já no segundo romance, Os Cus de Judas, a animalização dos soldados e do ambiente que os rodeia surge de um modo indirecto, através da caracterização dos animais do Jardim Zoológico de Lisboa, que estão aprisionados, e dos quais escuta "lamentos" (ANTUNES, 2008 , p. 12) torturantes. Sublinhe-se como essa é uma referência perniciosa, dado que reverte para o sujeito que se encontra na casa de banho da sua casa a defecar. Este indivíduo que presta atenção aos animais e que os refere como seres torturados, alegoriza sobre a situação do colonizado que, afinal, é a sua própria condição, pois, latu sensu, também ele é apenas um animal, resignado à alimentação e à defecação, a uma vida tendencialmente orgânica, destituída de um sentido. A tortura dos "animais" no Jardim Zoológico da sua cidade é, deste modo, transposta e intensificada para as torturas na guerra e, depois, no hospital, onde o alferes ingressa após o regresso de África.

Há uma inflexão: a tortura dos outros e/ ou sobre os outros é uma tortura autoinfligida na estrutura do sujeito como ser emocional e social. Aliás, o sujeito que parte para a guerra como um ser edipianizado e edipianizante (é casado e prepara-se para constituir 
família), regressa desedipianizado e dessocializado (separa-se da mulher que ama e das filhas que conhece não conhecendo, sendo esta a única "deserção" sobre a qual sofre "remorsos"), considerando-se assim como um "vagabundo associal". Este psiquiatra acaba por se relacionar com prostitutas (entidades tão marginais quanto ele, assim o sente), procurando não o amor, mas formas fugazes de ternura para as suas também efémeras sombras de Homem. Já na guerra, após a perda traumática de Sofia (a guerrilheira africana que é morta de forma animal pela polícia política portuguesa, a Pide), o alferes-médico encontrara momentos de paz na tabanca da Tia Teresa, uma casa de prostituição.

Em Lisboa apreende a semelhança entre as crianças e os cães, presentificação da guerra num lugar que esperava ser dissemelhante àquele em que vivera a guerra, mas, afinal, praticamente igual: "Como os cães e os putos se parecem nesta terra, se pareciam em África: a mesma expressão pedinte, o mesmo pêlo baço, os mesmos membros frouxos de lírio.” (ANTUNES, 2007b, p. 22) A miséria encontrada naquela que era a sua cidade, mas aonde regressa para se sentir deslocalizado, encontra paralelo na vislumbrada em Angola. Os encontros com prostitutas não se tratam apenas de uma inadaptação ao seu país, mas também de uma incapacidade para amar. Ora, as casas de prostituição, que também podem ser definidas por "lupanares" (palavra proveniente de lupus), revertem para a identidade do sujeito que foi à guerra, caracterizando-o como um "lobo" que se relaciona com prostitutas em relações sexuais próximas da animalidade. Salientemos que a prostituta com quem se relaciona na Memória de Elefante (ANTUNES, 2007a, p. 170) se chama "Dóri", o que, em nosso entender, pode reenviar a Os Lusiadas (CAMÕES, 1992, p. 219), em que a figura do Adamastor se apaixona por Thetis, filha de "Dóris". A consequência para aquele que foi um dia um gigante que combateu Júpiter é gravosa: metamorfose num gigante de pedra e condenação a viver atormentado pela assombração de Thetis, que passa a rondar naquelas águas. A crueldade de Dóris, a quem o gigante expusera a sua paixão, pode ligar-se ao estilema petrarquista que releva a crueldade da Dama, aspecto que, em Camões, é, como se sabe, constante. Mas na conhecida Ode IV de Camões, intitulada "Fermosa Fera Humana" (CAMÕES, 1994, p. 266-268), o sujeito fala também das "lobas isentas, que amor vendem", o que vem alterar a imagem petrarquista, isto é, o que, de certo modo, contraria as visões biografistas em favor das literárias.

Ora, no caso de Lobo Antunes, o combatente, como o Adamastor, torna-se num "penedo" (insensível, incapaz de amar) e vive de assombrações porque ficou retido no tempo da guerra (a imposição da imagem da pedra não é de menorizar). Por outro lado, 
Dóri não é propriamente uma "Fermosa Fera Humana", mas uma mulher que mastigava de boca aberta e usava dentadura postiça (ANTUNES, 2007a, p. 177 e 179). E, à medida que chegava a manhã, Dóri "regressava" a "uma juventude de criada de servir" (ANTUNES, 2007a, p. 177), o que nos leva a conjecturar que também ela seja uma visão literária que desmascara o mundo kitsch em que o sujeito (e o país que reencontra já em democracia) vive(m).

\section{V}

Os Cus de Judas iniciam-se com várias referências a animais, de entre elas se destacando o "cemitério dos cães" (ANTUNES, 2008, p. 9). A introdução desse tema na página inicial antecipa que o sujeito passará por um processo de transformação: "Nós não éramos cães raivosos quando chegámos aqui [...]" (ANTUNES, 2008, p. 136). Antes de mais, devemos sublinhar que já em Memória de Elefante (ANTUNES, 2007a, p. 64-65) o sujeito refere que a professora lhe pediu para desenhar os bichos do zoológico e o que ele desenhou foi o cemitério dos cães. Então, a localização desse cemitério, bem como a sua reiteração, não são inócuas, pois situa-nos, com precisão, num lugar que é um fim ou, porventura, um reinício, onde "o meu cadáver será lançado na última página, como o de um cão, para o fundo de um barranco" (ANTUNES, 2008, p. 48).

Por outro lado, também na Memória de Elefante (ANTUNES, 2007a, p. 126) se refere à experiência iniciática de uma empregada que pasma ante os animais do zoológico, entreabrindo efectivamente perspectivas que se encontrarão apenas no segundo romance, quando refere "Mangando e os latidos dos cabíris nas trevas, cães esqueléticos de orelhas de morcego" (ANTUNES, 2007a, p. 104). Esta referência ocorre em simultaneidade com a tentativa de suicídio do soldado, uma tentativa que o leva a agonizar durante quatro horas, lançando "grandes sombras confusas" nas paredes (ligação a um teatro de sombras que, afinal, parece ter sido a guerra colonial para a sociedade que o regime estado-novista ditava ainda ser "Lusa", e que o regime democrático não soube dilucidar). Também em Os Cus de Judas, onde a referência se torna mais obsessiva, encontramos os "cabíris" que "latiam atrás das galinhas magras de quimbo em quimbo" (ANTUNES, 2008, p. 162). Os "cabíris"3 simbolizam a ligação entre a cultura ocidental e a cultura africana, e impõem uma ligação

\footnotetext{
3 O uso da palavra "cabíris" (cão pequeno, rafeiro) é aqui importante também pelo facto de o termo ter origem no quimbundo "kabiri", sendo a utilização de palavras que têm uma origem etimológica em dialectos locais uma contestação do cânone.
} 
do sujeito da narrativa à personagem de Caliban (de que adiante falaremos em pormenor), que se liga à terra, ou seja, à matéria, ao mundo dos mortos.

Note-se como n' Os Lusíadas, e em particular no Canto IX, é o livro que decide o destino dos navegadores, e fá-lo entregando-os (antes do regresso à pátria) a uma vida de sensualidade e prazeres. Afinal, os nautas estão carentes de amor pátrio e só as ninfas, como seres celestes, podem sustentá-los de tal carência humana. Então, os navegadores correm, "veloces mais que gamos", como "galgos", perseguindo as presas (CAMÕES, 1994, p. 356). A imagem de sucesso é uma idealização, uma espécie de luz edénica, mas que oculta uma realidade mais amarga: a animalização dos nautas. Os argonautas são uma espécie de holograma de Pã, que era meio humano, meio animal, e que representa a voracidade sexual, perseguindo, sem escrúpulos, as ninfas, tal como os navegadores da armada de Vasco da Gama.

Pã liga-se ainda à mitologia pagã (CHEVALIER e GHEERBRANT, 1994, p. 500), que, como sabemos, coexiste com a mitologia cristã n' Os Lusíadas. De facto, a comparação dos mancebos a "galgos" que, pelo acto sexual (metáfora do ser canibal), conquistam as ninfas, revela a sua canibalização. A comparação dos navegadores aos cães tanto pode ser lida como um símbolo de impureza (ou seja, de uma corruptibilidade que acaba por resultar de um acto inicialmente tido como civilizador), como de glorificação. De facto, para os celtas, comparar um herói ou um guerreiro a um cão era uma honra e já não tem, como para os romanos, um significado negativo (cf. CHEVALIER e GHEERBRANT, 1994, p. 154). Deste modo, estamos em crer que Lobo Antunes substitui a Ilha dos Amores pelo Cemitério dos Cães, o que, a bem dizer, é também ambivalente, ambivalência essa que corresponde ao que foi a guerra colonial. Note-se como em Os Cus de Judas há uma referência aos "cães magros como galgos" (ANTUNES, 2008, p. 18). Os combatentes portugueses do século XX são outros portugueses que regressam à pátria sem que esta reconheça o seu esforço, e onde Penélope só pode materializar-se na figura de uma "loba". Todavia, e como vimos, este Luso não alcança a imortalização porque não há qualquer ilha dos amores, nem é capaz de ter a voracidade sexual que caracterizara Pã (símbolo da voracidade sexual), pois na viagem de avião para Portugal o alferes-médico conhece uma hospedeira com quem se relaciona, mas acabando por ser incapaz de consumar o acto sexual. 
Numa análise ponderada, devemos lembrar que é com a guerra que o país desperta lentamente para a realidade do seu papel em África e na Europa (PAGE, 2009, p. 284). Esta díade parece ser irrisória naquela época, mas a percepção de uma presença anacrónica em África, constatada empiricamente, coloca Portugal na transição para o pós-colonial. A guerra colonial será, em suma, o factor de depauperação das Forças Armadas Portuguesas, que se digladiam pelas carreiras e patentes. Indirectamente, o peso das comissões que os milicianos carregam e que os distancia dos militares do Quadro Permanente, que conseguem mover influências a nível governamental para se manterem afastados das zonas operacionais, gerará uma necessidade de um golpe militar (REBOCHO, 2009, p. 379 e 438) ou, mutatis mutandis, a guerra colonial é a grande motivadora do golpe de Estado que, a 25 de Abril, desemboca numa revolução popular. Parece, pois, incompreensível a hostilidade que a pátria manifesta para com os seus "filhos", e que se deve a um ressentimento histórico e a uma incomodidade para com cerca de cinquenta anos de ditadura.

Como temos vindo a verificar, a ligação entre o cão e o combatente parece ser predominante na obra de Lobo Antunes. O facto é que a origem latina da palavra cão é canis, palavra que forma o prefixo de canibal. Deste modo, a palavra "caliban" poderia ser um anagrama de "canibal", o que redunda nos comportamentos animalizantes dos combatentes. Por exemplo: “- Porque é que não abrimos a urna e comemos ambos um pedaço do ombro do Pereira?" (ANTUNES, 2004, p. 144) Os soldados não são, portanto, vistos como vítimas do regime ou cumpridores das ordens políticas e militares, mas como os canibais de um tempo. A vivência na guerra é, por essa razão, compassada pela presença dos cães: “à noite os cães selvagens ladravam em torno do arame Está a ouvir os gajos sussurrava o tenente" (ANTUNES, 2008, p. 113).

Os cães "esqueléticos" (ANTUNES, 2008, p. 10), de "olhos suplicantes" (ANTUNES, 2008, p. 66), representam a fome, a miséria, a hediondez da guerra, de tal modo que o soldado que se tenta suicidar vê momentaneamente frustrada a sua tentativa. O absurdo não é mais a tentativa de suicídio, mas uma tentativa falhada que o leva a agonizar prolongadamente durante quatro horas, lembrando a constância dos cães em torno do quartel. A comparação é por demais evidente quando verificamos que as sombras emitidas pela agonia do soldado se assemelham à imobilidade dos cães: "as sombras estenderam-se no soalho numa vergonha de cachorros, subitamente imóveis" (ANTUNES, 2008, p. 179). Essa imobilização é a de uma espera paciente pelos restos de que possam 
alimentar-se: "cães vadios a lamberem restos na parada" (ANTUNES, 2008, p. 176). A persistência dos cães é de tal modo perturbadora que o médico tem vontade de sair para os enxotar, porém, quando sai para o exterior da enfermaria, os cães mostram-se gulosos dos restos de sangue que lhe pejam a roupa. Vejamos:

De pé, à porta da sala de operações, com os cães do quartel a farejaremme a roupa, gulosos do sangue dos meus camaradas feridos, a lamberem o sangue dos meus camaradas feridos nas nódoas escuras das minhas calças [...] (ANTUNES, 2008, p. 165)

Esta canibalização do cão associa-os à imagem da corruptibilidade e, em suma, à luta desesperada e louca pela sobrevivência. De facto, para Maria Alzira Seixo, os cães representam: "uma paisagem vazia ou deteriorada, raramente como agentes, antes como entidades submissas e sofredoras e caracterizam ambientes como os da guerra" e [...] "prolongamento da presença debilitada e dolorida (e por isso eventualmente agressiva) dos seres humanos" (SEIXO, 2008, p. 79). A calibanização é representada pela alienação que afecta os soldados e que os leva a ter comportamentos em nada consentâneos com a sua moral anterior à guerra. A alienação representa, aliás, a situação de des-localização física do soldado em relação ao seu país e, por outro, a sua alteração psicológica reflectida em níveis comportamentais que atingem a loucura. Os soldados oscilam, assim, entre momentos em que se comportam como "animais" e outros, em que reflectem e se apercebem da sua própria mutação, que, contudo, não conseguem compreender. Vejamos alguns exemplos em que se patenteia esse conjunto de comportamentos anómalos: “[...] nos divertíamos mordendo-nos como os animais [...], nos ameaçávamos com as pistolas, [...], numa raiva invejosa de cães, nos espojávamos, latindo [...]” (ANTUNES, 2008, p. 181).

A importância dos cães encontrados na guerra não se limita a ser um novo conhecimento, mas exige uma reavaliação da infância. Como afirma Maria Alzira Seixo (SEIXO, 2008, p. 75), a relação entre os animais e o homem em Lobo Antunes "prende-se a evocações de infância, e é agudizada pela estada na guerra em África”. Vejamos como já em Os Cus de Judas a guerra evoca a infância e a ela se conecta. Aí encontramos um exemplo em que as mortes de um furriel e outros camaradas na guerra, de quem ouve as vozes, servem de estímulo para uma recordação remota: "a voz do meu cão morto há muitos anos" (ANTUNES, 2008, p. 163). No fundo, a morte do seu cão é o terminus da sua infância, ou melhor, é a sua maturação à custa da "virgindade" moral e intelectual. Ora, na Odisseia, Ulisses regressa à casa após a guerra de Tróia e o seu cão, Árgus, morre de emoção 
ao ver o seu dono. Esta morte representa a fidelidade, a quase humanidade do animal, e é comovedor verificar que o cão parece esperar pelo dono para morrer. Em Os Cus de Judas não há qualquer visão epopeica, antes a constatação de que o cão morre antes de ele partir e ninguém o vem receber e/ ou chorar.

O sujeito parece definitivamente afectado pela imagem dos cães, que se entrecruzam com a sua actividade de médico, como forma de encarar os mortos e inclusive como forma de ter conhecimento de Sofia, uma vez que, na noite após a ter conhecido, diz: "enxotei os cães que rondavam a messe em elipses de fome submissa e teimosa" (ANTUNES, 2008, p. 165).

\section{VII}

No processo de ressocialização, os soldados revelam comportamentos canibalizantes. O canibalismo liga-se, em Lobo Antunes, a duas actividades: a de médico e a de soldado. Estas contraditam-se, mas estão presentes, em simultâneo, na obra antuniana. O alferes-médico, que, teórica e ficcionalmente, representa o autor empírico, é um médico que comete actos canibais. Ora, a actividade de médico (e ainda mais de um médico que procura curar ou salvar sujeitos de ambos os lados da guerra, o que o coloca numa posição, digamos, marginal) ou a medicina ocidental seriam ferramentas do Euroexpansionismo (cf. PRATT, 1992, p. 83). O "primeiro Lobo Antunes" faz-nos confrontar com um médico ocidental que atesta a falha da medicina canónica perante a sabedoria milenar africana, o que demonstra a falência do próprio Ocidente. Tal assunção é reforçada no momento em que o médico, regressado da guerra, empreende uma viagem pelo inferno das coisas. Esta viagem é de tal modo metafórica que o médico, como ex-combatente, imagina cometer actos de canibalismo (ANTUNES, 2004, p. 144). Além das situações referidas, é importante sublinhar que a amputação de uma perna ferida por um médico ocidental pode ser considerada como um acto de canibalismo (cf. PRATT, 1992, p. 83). Finalmente, o canibalismo emerge também através do acto sexual, como verificamos no exemplo seguinte: "penetrarei em si, percebe, como um cachorro humilde e sarnento num vão de escada para tentar dormir" (ANTUNES, 2008, p. 180).

Por outro lado, a figura do demónio é muitas vezes ligada à sexualidade e em particular ao ânus (MARTINEZ e MAXWELL, 2007, p. 301). Temos, pois, que (re)considerar o título Os Cus de Judas, que, segundo essa perspectiva, se conecta com uma 
sexualidade que entendemos ser canibalizante. Os Bambaras comparam o cão ao pénis e muitas vezes o pénis é designado como cão. Esta ligação resulta de uma analogia "entre a cólera do pénis, a erecção diante da vulva, e o latido de um cão diante de um estranho" ou entre "a voracidade sexual do homem" que só tem "paralelo na fome canina" (CHEVALIER e GHEERBRANT, 1994, p. 153). Também segundo o Novo Dicionário do Calão (PRAÇA, 2005), a palavra “judas” significa exactamente “pénis”. Ora, nesse sentido, a expressão os-cus-de-judas estabeleceria uma ligação entre a humanidade e a animalização do soldado. Em suma, o cão representa um antinómio, que, no livro antuniano, pretende uma expulsão.

Por esse motivo, no romance antuniano a alma do sujeito já não se assemelha à da epopeia, em que o herói nunca põe nada em jogo por ignorar os riscos. Em Lobo Antunes a alma do herói já conhece o abismo e, por isso, não se ignora (cf. LUKÁCS, 1970, p. 2829). E, sobretudo, avaliza-se pela sua identidade, patente em Os Cus de Judas, romance em que o alferes-médico leva a cabo uma espécie de exortação aos governantes do país, fossem eles os da ditadura, sejam eles o da democracia, que entrevê como um ideal frustrado onde só o bestiário parece ser metáfora suficientemente inteligível.

\section{Bibliografia Activa:}

ANTUNES, António Lobo. Memória de Elefante. Lisboa: D. Quixote, 2007a. Fado Alexandrino. Lisboa: D. Quixote, 2007b. Os Cus de Judas. Lisboa: D. Quixote, 2008. Conhecimento do Inferno. Lisboa: D. Quixote, 2004. Cartas da Guerra. Lisboa: D. Quixote, 2005.

CAMÕES, Luís Vaz de. Os Lusíadas. Lisboa: Biblioteca Ulisseia de Autores Portugueses, 1992.

Rimas, texto estabelecido e prefaciado por Álvaro da Costa Pimpão, Coimbra, Livraria Almedina, 1994.

FERRAZ, Carlos Vale. Os Lobos Não Usam Coleira. Lisboa: Editorial Notícias, 1995.

PACHECO, Fernando Assis. A Musa Irregular. Rio Tinto: Edições Asa, 1996. Respiração Assistida. Lisboa: Assírio \& Alvim, 2003.

PIRES, José Cardoso. A Balada da Praia dos Cães - Dissertação Sobre Um Crime. Lisboa: Planeta de Agostini, 2001.

\section{Bibliografia Geral:}

BEBIANO, Rui. A Pena de Marte: Escrita da guerra em Portugal e na Europa (sécs. XVI-XVIII). Coimbra: Minerva, 2000.

CARVALHO, Bernardo. "Um Oceano de Ressentimentos". in Folha de S. Paulo. São Paulo, 22 de Abril de 1999.

CHEVALIER, Jean, e GHEERBRANT, Alain. Dicionário de Símbolos. Lisboa: Teorema, 1994. 
COELHO, Jacinto do Prado. Originalidade da Literatura Portuguesa. Lisboa: Biblioteca Breve / Instituto da Cultura e Língua Portuguesa, 1992.

KEEGAN, John. Uma História da Guerra. Lisboa: Tinta-da-China, 2006.

LUKÁCS, Georg. Teoria do romance. Lisboa: Editorial Presença, 1970.

MARTINEZ, Maria, e Maxwell, Richard. Ciências Ocultas. Lisboa: Planeta Editora, 2007.

PAGE, Martin. 2009. A Primeira Aldeia Global. Lisboa: Casa das Letras, 2009.

PETROV, Peter. "A componente ideológica em Balada da Praia dos Cães de José Cardoso Pires”. in O Romance Português Pós-25 de Abril. Lisboa: Roma Editora, p. 11-23, 2006.

PRAÇA, Afonso. Novo Dicionário do Calão. Lisboa: Casa das Letras, 2005.

PRATT, Mary Louise. Imperial Eyes: Travel Writing and Transculturation. London \& New York: Routledge, 1992.

REBOCHO, Manuel Godinho. As Elites Militares e a Guerra de Africa. Lisboa: Roma Editora, 2009.

RIBEIRO, Margarida Calafate. Uma História de Regressos: Império, Guerra Colonial e PósColonialismo. Porto: Afrontamento, 2004.

ROUSSEAU, Jean-Jacques. O Contrato Social. Lisboa: Europa-América, 1999.

SEIXO, Maria Alzira. "Bestiário", in Dicionário da Obra de António Lobo Antunes (Volume II). Lisboa, Imprensa Nacional-Casa da Moeda, p. 75-86, 2008. 